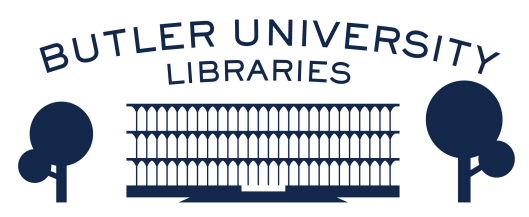

Journal of Hindu-Christian Studies

Volume 16

Article 9

January 2003

\title{
Ethics and Genetic Engineering in Indian Philosophy, and Some Comparisons with Modern Western
}

Harold Coward

Follow this and additional works at: https://digitalcommons.butler.edu/jhcs

Part of the Religion Commons

\section{Recommended Citation}

Coward, Harold (2003) "Ethics and Genetic Engineering in Indian Philosophy, and Some Comparisons with Modern Western," Journal of Hindu-Christian Studies: Vol. 16, Article 9.

Available at: https://doi.org/10.7825/2164-6279.1298

The Journal of Hindu-Christian Studies is a publication of the Society for Hindu-Christian Studies. The digital version is made available by Digital Commons @ Butler University. For questions about the Journal or the Society, please contact cbauman@butler.edu. For more information about Digital Commons @ Butler University, please contact digitalscholarship@butler.edu. 


\title{
Ethics and Genetic Engineering in Indian Philosophy, and Some Comparisons with Modern Western Thought
}

\author{
Harold Coward \\ University of Victoria
}

\section{Ethics and Genetic Engineering in Indian Philosophy}

NO matter how many railway trains we run and telegraph lines we lay, in the field of power we remain infinitely far from God. If we dare to compete with God, then our endeavour, transgressing its limits, becomes cursed and faces annihilation. No scientist, no technologist, has the ability to plumb completely even a grain of dust within which he resides. Therefore the person who would compete with God in the sphere of power is like Arjuna shooting arrows at the distinguished Mahadeva - arrows that do not touch him. Defeat there is inevitable.

Rabindranăth Togore, from a 1908 morning discourse at Shantiniketan ${ }^{1}$

What is added on later [culture] is always liable to predominate over what was there in the first place [nature].

$$
\text { - Derrida, Supplements }{ }^{2}
$$

\section{Introduction}

In the context of India, Genetic Engineering research and technology is well underway. The Government of India has issued statements indicating that India "will fully utilize the availability of genetic engineering resources . . f for maximizing output besides working out a sustainable program . . .".3 Between November 22, 1998 and March 21, 1999 no less than 32 stories of genetic

\footnotetext{
Harold Coward is a Research Fellow and former Director, Centre for Studies in Religion and Society, University of Victoria, Victoria, BC, Canada. His many books include: Jung and Eastern Thought (1985); The Philosophy of the Grammarians (1990); Derrida and Indian Philosophy (1990); Pluralism in World Religions (2000); Scripture in World Religions (2000); Yoga and Psychology (2002); T.R.V. Murti (2003); and Sin and Salvation in World Religions (2003). His edited book, Indian Critiques of Gandhi will appear with SUNY Press this fall. He is currently at work on Hinduism and Human Rights for Greenwood/Prager. He is a Fellow of the Royal Society of Canada, serves on the Nominations Committee of the AAR, and is Chair of the Ethics Committee for Genome BC. From 1988-2002 he was Editor of The Hindu-Christian Studies Bulletin.
} 
engineering research or technology developments appeared in India media sources - particularly the PTI News Agency and the Inter-Press Service in Delhi. ${ }^{4}$ The research spans a wide range from genetic studies of the human population of the Indian sub-continent to various agricultural applications, often involving multinational corporations such as Monsanto. While the latter have evoked significant farmers' protest movements causing the government to reverse its policy decisions, the former seem to have engendered little media comment or public response.

Of the former, namely human genetics studies, two examples are as follows. Under the headline, "Indian scientists develop software for decoding 'genetic' secrets," the PTI News Agency (Delhi) reports a computer software program developed by the Indian Institute of Chemical Biology (IICB) that can decode protein sequences in genetic materials of all living organisms. This computer record keeping system, it is claimed, will revolutionize the genetic analysis of life activities such as reproduction, metabolic function and morphogenesis. It is currently being used to analyze protein sequences of the kala-azar causing parasite and the tubercle bacillus. ${ }^{5}$ Moving from this potentially useful medical application, the second example is one that uses genetic analysis to examine the effects of the caste system upon Hindus. Research from Andhra University collected blood samples from 250 unrelated men from 12 Telugu-speaking peoples spanning all castes in northeastern Andhra Pradesh. Analyzing the collected blood with molecular tests, the scientists found that in the genetic make-up of Hindus, there is "great divergence" between the upper and lower castes - the "genetic distance" between upper and lower castes being one and one-half times greater than between upper and middle or middle and lower classes. Thus lower castes and higher castes are shown to have become genetically different, and this difference is greater as the caste disparity widens. ${ }^{6}$ With a similar objective, a 1986 study attempted to collect all the genetic data published to date in twelve leading journals on genetics on the populations of the Indian subcontinent. The study was titled, The distribution of Human Genetic Polymorphisms in India - with Special Reference to the Hindus, and aimed at using genetic information to reconstruct the recent evolution of the Hindus. ${ }^{7}$ This overly ambitious study concluded that a much larger body of data than currently available would be needed to achieve a genetic study of the large and composite Hindu population of the Indian subcontinent.

Much more of India's genetic research and engineering is going on in agriculture (especially in the area of genetically altered seeds) and in the pharmaceutical study of traditional plants. In the latter category, a US company, basing itself on the knowledge of traditional farmers that the neem tree of India provides a natural pesticide, has engineered a product which it has now patented and for which the indigenous people of India receive no credit. $^{8}$ The problem here is that the many indigenous cultures and peoples of India are seen as treasure houses of diverse genetic knowledge by large corporations, who patent and commercially exploit this knowledge, usually without reference to the indigenous culture from which the knowledge was obtained. More troubling, however, is what is occurring in the genetic alteration and patenting of seeds, placing them under corporate control and taking them out of the hands of ordinary farmers. For example, Monsanto has formed a joint venture with Mahyco (a 30 year old seed company in India) to carry out field trials on hybrid cotton seed that has been genetically engineered to produce the Bacillus thuringiensis $(\mathrm{Bt})$ enzyme, so that chemical insecticide sprays will no longer need to be used for pest control (e.g., bollworms). While this technology may be preferable to the spraying of insecticides option, more troubling was the involvement of Monsanto in India in testing the so-called "terminator 
gene," which allows plants to grow but not produce seed for future crops. When the government of India discovered in 1998 that Monsanto was conducting field trials on the "terminator gene" seeds at a private farm in the Haveri district, Mr. Patil, Minister for Rural Development, declared that the terminator gene seed will pose a serious threat to Indian agriculture, and that Monsanto will be asked to leave India. It was recognized that such an action could place India in trouble with the World Trade Organization. ${ }^{9}$ As we will note later, events such as this have raised widespread protest among NGOs and farmers' groups in India. These groups have responded to Monsanto and other such corporations with charges of biopiracy. The Indian ecofeminist activist, Vandana Siva, has been a leading spokesperson in this regard.

Let us conclude this introductory contextualization into the genetic engineering activity going on in India today, by rehearsing the policy position of the Indian Government. As we have noted, the government officially welcomes genetic engineering into India as part of its economic development plan. However, India also has strict regulations in place governing every phase of genetic engineering, from research in the laboratory to trials in greenhouses, field trials and final release. ${ }^{10}$ But these regulations may not cover the important ethical issues involved. Given the strong activity in Genetic Engineering in India, this paper asks, "What ethical principles can be found in Indian Philosophy and Religion that may be of help?"

\section{Ethical Issues Arising from Basic Presuppositions of the Indian Worldview}

Traditional Indian philosophy assumes a worldview that is quite different from the European worldview of modern thought. When the ethics of genetic engineering are examined in the Indian context, issues arising from the traditional Indian worldview must be considered as well as those coming from modern European thought. Two presuppositions of traditional Indian philosophy that should be examined for implications with regard to genetic engineering are (1) karma-samsara and (2) views of "evolution that contrast with Darwinian natural selection. Let us briefly examine each of these in turn for their ethical implications for genetic engineering.

\section{Karma-Samsara Theory.}

The first thing to note is that in karma theory, unlike much European thought, nature is not separated from humans and subjected to human domination. Karma theory rejects such dualism and maintains, especially from a Jaina perspective, that there is no radical separation between humans and other forms of beings (animals, plans, air, water, molecules of matter). Instead, a radical continuity is proposed which has ethical implications for much genetic engineering.

From the Jaina perspective, humans, animals, plants and molecules of air, earth or water are all composed of souls (jivas) entrapped in varying kinds of quantities of karma. Karma, for the Jainas, is composed of material traces of past actions that "float free" in every part of space and adhere to the soul because of the "stickiness" of the passions (kasayas), desire (raga) and hatred (dvesa) with which it is covered. ${ }^{11}$ For our purposes, it is not necessary to delineate the Jaina view of the various kinds and colors of karma that stick to and weigh down the soul, causing it to appear as earth, water, air, plant, animal or human. Suffice it to say that all are in varying levels of karmic bondage in which they will be continually reborn until a complete release from karma is achieved.

For the Jaina, the most powerful force to move one toward the goal of release is the practice of non-violence (ahimsa) in everything one thinks or does. ${ }^{12}$ Thus, the Jaina ethic of non-violence requires not just 
reverence toward other humans, but also reverence toward souls which, because of their particular karmic covering, appear as animals, plants, rocks, earth, water or air. One cannot imagine a more comprehensive and exhaustive application of a non-violence ethic than the Jaina theory of karma produces. Certainly there is no room for human domination and exploitation of other states of nature which, for the Jaina, are simply souls (jivas) in other karmic forms. While few may be willing to accept the Jaina prescription, namely, the practice of non-violence (ahimsa) toward all forms of life (human, animal, organic, and inorganic) leading ultimately to the freely chosen act of self-starvation (sallekhana), the strong emphasis upon the need to reverence life in all its forms, including even the inorganic, has been influential in India. ${ }^{13}$

Reverencing plant and animal life offers important correctives to modern agriculture and its use of monoculture, chemicals and genetic engineering. Insertion of the terminator gene, resulting in a failure of the plant to be able to reproduce, would, in the Jaina view, seem to deny that soul the opportunity to be reborn and move closer to ultimate release. More to the point, however, is a consideration of the suffering that many be involved in the application of genetic engineering to animals. Proponents of genetic engineering often look at the process of animal engineering and its results strictly from the human perspective - from the benefits that will accrue to humans. For example, genetically engineered "super pigs and chickens" may increase the amount of food for human consumption. But what about the effect upon the animals themselves? Or consider medical research. Animals are genetically engineered to model some of the most devastating diseases that afflict humans. To accomplish this goal, however, requires that large numbers of animals live lives of intense pain and suffering. The ethics of inflicting such suffering upon animals so as to potentially benefit humans has received little attention in the West. However, for the Jainas, these animals are beings to whom the ethical principle of ahimsa or non-violence applies with equal force as it does to humans. Thus, Jaina ethics, with which most Hindus and Buddhists would agree, requires the control and regulation of the degree of animal suffering involved in the genetic engineering of animals in the two areas of agriculture and biomedicine.

While the Jaina conceptualization of karma theory may be too radical, in spite of its logical consistency, to be taken seriously by modern India, the Yoga analysis of karma entails a moral responsibility that cannot be sidestepped. There are many definitions of karma in Indian thought, some making karma appear quite deterministic or fatalistic, others emphasizing the role of free will, giving karma a strong moral responsibility. The latter is especially true if we examine the conception of karma found in Patanjali's Yoga Sutras. ${ }^{14}$ Karma is described by Patanjali as a memory trace (samskara) recorded in the unconscious by any action or thought a person has done. We should note here that, for Yoga, a thought is as real and as important as an action - we think first and then act, so thought is therefore of primary significance. The karmic memory trace (samskara) remains in the unconscious as a predisposition towards doing the same action or thought again in the future. All that is required is that the appropriate set of circumstances present themselves as the karmic memory trace, like a seed that has been watered and given warmth, bursts forth as an impulsion toward the same kind of action or thought from which it originated. If one, through the exercise of free choice, chooses to act on the impulse and do the same action or thought again, then that karmic seed is allowed to flower, resulting in a reinforcing of the memory trace within the unconscious. Sufficient repetitions of the same action or thought produce a strengthening of the predisposition (samskara), and the establishing of a habit pattern or vasana. 
Such a karmic habit pattern or vasana is the Yoga equivalent for the modern psychological notion of motivation. The unconscious, in Yoga terminology, is nothing more than the sum of all the storedup karmic traces of freely chosen actions and thoughts done in the past.

Notice that, in the above analysis, the karmic impulse from the unconscious does not cause anything, it is not mechanistic in nature. Rather, it simply predisposes you to do an action or think a thought. It is all up to your own free choice, which means that the moral responsibility for your choices rests squarely upon your own shoulders. Even the initial impulse arising from the samskara or memory trace in the unconscious got there in the first place by a freely chosen action on your part in the past and therefore it is an impulse for which you are morally responsible. Consequently, in the Yoga view of karma, there is no escaping the moral responsibility for the actions one chooses to do or even the impulses toward action arising from one's unconscious. Thus, through the use of your own free choice, you decide either to go along with the karmic impulse, in which case it is reinforced and strengthened, or to say "no" and negate it, in which case its strength diminishes until it is finally removed from the unconscious. Karmas can be either good or bad. Good actions and thoughts lay down good karmic traces in the unconscious for the predisposing of future good karmic impulses. Evil actions and thoughts do the reverse. Scripture and tradition taken together distinguish between good and evil. And with regard to the continuum of nature (of which we humans are a part), Jaina, Hindu and Buddhist traditions all agree that the nature is to be reverenced and not harmed. We have detailed the Jaina view in this regard above.

There is one more aspect to the way in which karma functions that must not be forgotten. We have seen how, according to the theory of karma, we are each morally responsible for the good or evil thoughts or actions toward nature (humans and animals) that we freely choose to do during this life. But according to Yoga and Indian thought generally, that moral responsibility extends backward to include all the actions and thoughts of our previous lives - which created the dispositions toward the environment we are currently experiencing. This is the notion of samsara or rebirth. According to this concept, one's unconscious contains not only all the karmic traces from actions and thoughts done in this life, but also in the life before this and so on backwards infinitely since, in Indian thought, there is no absolute beginning. In reality, then, one's unconscious is like a huge granary full of karmic seeds or memory traces that are constantly sprouting up, as conducive situations arise, impelling one toward good or evil actions or thoughts. From the point of view of environmental ethics, this means that the impulses $I$ am now feeling in the way I behave toward animals, plants, earth, air and water are a direct result of the way I have freely chosen to behave in past lives. If my arising karmic impulses are suggesting irresponsible or exploitative behaviour, it is because I have acted in immoral ways toward nature in this and previous lives. And since I chose to behave in those ways, I created for myself the impulses now arising from my own unconscious. If I find myself wanting to cut down the forest, foul the water, pollute the air and selfishly exploit earth's animals and resources by genetic engineering, I cannot blame these impulses on God, the devil, my parents or society. They are coming into my mind at this time because I laid them down as seeds or memory traces in my unconscious in the past (in this or previous lives). So I, alone, am responsible for the impulses, good or bad, that I am now experiencing.

But I am not fatally trapped by my past environmental karma. In spite of my impulses toward action, I still have the free choice to go with or to negate such impulses. While I may have habitually 
fouled the air and selfishly exploited nature in past actions (in this and previous lives), I can still use my free choice now, when the situation arises, not to accept such an impulse again. According to karma theory, it would be as if a seed has sprouted and not been given moisture or warmth causing it to wither and die without flowering. By using free choice to negate irresponsible environmental impulses when they arise, it is as if they are receiving no water or warmth and thus die without flowering into a repeated action. In this way, over repeated good choices, environmentally destructive karmic patterns can be removed from my unconscious and replaced by good environmental impulses. From the perspective of karma theory, I am totally responsible for both my impulses toward the environment, and the way I choose to act or not act on those impulses. And the way I choose to act today creates the karmic impulses I will experience tomorrow and in future lives in my interdependent interaction with nature. I, alone, therefore, am responsible for the condition I will create for the future.

But it is not just my own present and future I am creating through my acts of free choice. Remember that for karma theory, my existence as a being is not independent but in a continuum with all other beings with all of nature. Therefore, what I choose to think and do affects not only my present and future life, but also the rest of nature of which I am an interconnected part. In this regard, my karmic responsibility is both individual and cosmic. The way I make my choices conditions not only my future lives but also the future of all other beings which, in the karma perspective, includes all of nature (all humans, animals, plants and molecules of matter). How does this understanding of karma theory relate to genetic engineering?

Just as we had to begin by demonstrating that karma theory does not end in determinism, the same is the case with regard to genetic engineering. Popular descriptions of genetic engineering in humans (e.g., parents selecting the characteristics they want in their children), in animals or plants often present the issue as a clear case of cause-effect scientific determinism. In reality, however, geneticists draw a distinction between the genetic endowment of an organism (its genotype) and the characteristics the organism manifests (its phenotype). "This distinction arises from an awareness that there is no simple relation between individual genes and characteristics, and, more specifically, that genes do not determine characteristics. The phenotype is the product not only of the genotype, but also of the complex interaction between genotype and environment." ${ }^{15}$ Already we notice interesting parallels with karma theory. Just as karmic memory traces (samskaras) predispose but do not determine the manifestation of particular actions, so also individual genotypes predispose but do not determine the appearance of phenotypes or characteristics. And just as human free choice makes moral choices in deciding which karmic dispositions to actualize and which to negate, so also genetic engineering sees itself as "enhancing" or therapeutically changing one's characteristics. But as with karma theory, the question can be asked, how do you tell the good from the bad? The Yoga answer is that 'scripture and tradition decides. In genetic engineering, the situation seems more complex. Therapeutic goals often seem more clearly good than enhancement goals (e.g., more intelligent, better memory, etc.). Once we begin to make genetic modifications, we are unsure of the biological and social consequences for the individual and for the collective ecosystem of which the individual is but a part. Our modern scientific understanding of nature does not recognize anything like a norm of humanity that has intrinsic moral significance or that has an absolute moral claim on us. ${ }^{16}$ For those who accept the assumptions of karmà theory, can it offer any help with regard to moral issues? 
First, much genetic engineering today seems to be treated as a matter for market forces to decide - will it make things more efficient, productive and profitable? The karma analysis of such an act of genetic engineering (whether done on humans, animals or plants) would call into question the motivation of the one doing the genetic engineering and the possible impact on the organism being engineered. If it looked to be beneficial to the organism (not changing its own basic self-identity), and to the cosmos (without market conditions entering the picture), then it might be acceptable. This general principle would rule out uses that would likely work to foster unfair discriminations (racism, sexism), but perhaps not caste distinctions, since the latter can be seen as the result of one's own freely chosen karma (e.g., as in the Bhagavad-Gita with its counsel to live one's own karma rather than attempting to take on, by genetic engineering, the karma of someone else).

This brings us immediately to the most difficult and most basic question. Should one person (the scientist or corporation) be able to use genetic engineering to alter the basic makeup of another - be the other a person, plant or animal? In karma terminology, the question becomes should one person's karmic choice be able to fundamentally change (for good or for ill) the karmic makeup of another - a selfidentity created by the moral choices made by the other over countless lifetimes? In a way, such changing of the karma of one by the karma of another has always been happening as people meet and interact. However, the science and technology of genetic engineering proposes to make the rate and magnitude of the change much larger and faster. Does that mean that it should either be ruled out or placed under moral limitation? While this question in the West has been raised mainly to call into question the using of genetic technology to alter human characteristics, karma theory raises the question equally for animals and plants (for Jainas) - a significant widening of the field of ethical discourse.

In the West, this question is usually dealt with under the rubric, "Are we 'playing God'?" as, for example, in the 1977 book by Howard and Rifkin, Who Should Play God? This line of thought assumes that there is a God who has created all of this and that only God can understand God's creation (see Job), therefore any tinkering by genetic engineering will likely seriously mess up this plan, which only God can understand. Problems with this objection include considerations such as (1) since we cannot understand God's plan, how do we know what constitutes interference? and (2) as a general prohibition, this approach would also rule out things like prenatal care and Caesarian sections just as much as arrogant interference as genetic engineering. As there is no God in karma theory, this objection does not have the same force. In Indian thought, there is no absolute beginning. Things have been always going on. The karma one possesses today was not created by any God, but rather by the choices freely made in this life, the life before this, and so on backwards indefinitely. Thus, one is morally responsible for one's own karmic nature. In karma theory, one's rebirth to a particular couple (one's next parents) occurs because one's own karmic nature (Antahkarana which includes the buddhi, manas and ahankara and carries one's karmic identity from one birth to the next) seeks out a couple of like karma who are engaging in sexual intercourse (for a detailed description, see the Tibetan Book of the Dead). The changing of one's karmic nature by genetic engineering would result in a different rebirth for which one would not bear total moral responsibility - it could be either a better or worse rebirth than that which one's freely chosen karma would have predisposed. One might end up being more intelligent (sattvic), etc., than one might have been without the enhancement of genetic engineering. 'Of course, the intervention could go in the other direction 
(more dullness or tapas), depending on the intention of the genetic scientist (which in turn would be predisposed by his or her karma). Again, there is no God here, just the impact of freely chosen acts - but with the proviso that genetic engineering may make this impact much larger and more significant than it would otherwise have been.

\section{A Different Conception of Evolution}

Another issue raised in Western ethics discussions over genetic engineering relates to therapeutic interventions (e.g., to genetically cure sickle-cell anemia) that may be interfering with an evolutionary purpose (e.g., in black Africans, the presence of the sickle cell in its heterozygote state offers some protection against malaria) that we do not yet fully understand. Thus, until we have a better understanding of human evolution, perhaps we should not alter human genes. We may seem to produce a small good, only to lose a greater good that has evolved in nature. Is there a wisdom of evolution that transcends our current grasp and might be disrupted by a genetic engineering which focuses on a very small part of the total evolutionary processes and is so bold as to interrupt the process so as to make specific genetic changes?

In Indian thought, the situation is even more complex, for in traditional philosophy the evolutionary process proceeds top down from consciousness to ego-awareness to mental structure, sense organs, the body and external matter - all of this following the karmic heritage of the individual expressed in Yoga psychology in terms of the three gunas: sattva, rajas and tamas. Here "the wisdom of evolution" is contained in the individuals' self-created karmic heritage from previous lives. To mess with this, through genetic engineering, from below, would go against the whole logic of Patanjali's Yoga Theory.

Although traditional Indian thought imagined the process of evolution to occur top down (i.e., starting with consciousness, mind and ego, and then evolving "downward" to develop sense organs, a body, and physical matter) rather than "bottom-up" (the Darwinian view of natural selection), a contemporary Indian thinker, Aurobindo Ghose, attempts to combine the two approaches. Does genetic engineering fare any better in Aurobindo's approach? Aurobindo's ultimate concern was the perfection of the individual person, society and the entire phenomenal world. ${ }^{17}$ While some genetic engineering speaks of its goal as "human enhancement," Aurobindo aims for nothing short of universal perfection:

... the reason for which the Avatars descend is to raise man up again and again, developing in him a higher and even higher humanity, a greater and yet greater development of divine being, bringing more and more of heaven again and again upon the earth until our toil is done, our work accomplished and Sachidananda fulfilled in all even here, even in this material universe. ${ }^{18}$

All change must begin with the individual, but must end in the evolution of the whole world into perfection. Unlike genetics which might search for such complete knowledge in the mapping of the human genome, Aurobindo taught that true knowledge comes from turning the mind inward to its divine source. Such knowledge gives a vision of reality in its totality. It is a higher knowledge than the knowledge of science, art, philosophy, ethics, psychology. It is a knowledge of Reality which arrives as a full direct yogic vision, ${ }^{19}$ which sees that nature has been manifesting herself by evolution successively from matter to life, to mind, and finally to spirit above mind. The danger of genetic engineering is that it may become fixated upon the matter aspect of evolving nature and think that that is everything. This 'would reduce the awareness of humans of themselves and 
46 Harold Coward

their dynamic spiritual world to a fixation on the material level - a knowledge limitation that would be morally unacceptable because of its "smallness" and its lack of humility in the face of the divine.

To achieve the evolutionary goal of perfection of the universe, says Aurobindo, requires a knowledge and practice that is higher than the science and technology of which genetic engineering is a part. It requires what Aurobindo called "integral knowledge," a higher knowledge attained by the practice of yogic meditation - a direct knowledge of reality which arrives at "the full vision." This is not an intellectual knowledge which can be learned; it is a knowledge which must be experienced and realized. ${ }^{20}$ The application of all of this to ethics and genetic engineering is straightforward. For the application of genetic engineering to be ethical, it must be guided by the goals of the higher "integral knowledge" and not be left to the lower aspirations of ego-enhancement, power over nature for human overconsumption, or uncontrolled greed of the market economy. However, I do not think Aurobindo's vision would rule out genetic engineering, for Aurobindo embraces science and matter in the realization of his ultimate vision. In this respect, Aurobindo offers an interpretation of the Upanisads that differs from that of the Advaita Vedanta school. Instead of ultimately negating or transcending nature (the Advaita Vedanta position), Aurobindo affirms the material aspects of life and, through a process of spiritually directed evolution or becoming, sees matter moving toward mind and ultimately divine Spirit. Thus, for Aurobindo, nature has within itself an irresistible ascending evolutionary force. Ethical action in genetic engineering would be action in line with this divine evolutionary process. To achieve this, the genetic scientist (or corporation) would have to practice Aurobindo's yogic meditation so as to have the lower activity (science and genetic engineering - saguna knowledge) guided by the higher integral or unified knowledge of the yogic vision. (The thought of a corporation such as Monsanto practicing yogic meditation does boggle the mind!) Today, we might call this "integral knowledge" an "ecosystem knowledge" so long as our conception of ecosystem was grounded in the divine.

Another characteristic of the ethical application of genetic engineering within Aurobindo's vision is that the genetic scientist or technologist, would be characterized by humility since, according to Aurobindo, knowledge of Absolute Reality transcends our limited conceptual comprehension. $^{21}$ This highlights a difference in terms of Western discussions of ethics, evolution and genetic engineering. In Western thought, it has been suggested, while somatic or non-inheritable genetic modifications are acceptable, germ-line or inheritable genetic modifications should be prohibited as interfering with the wisdom of natural (Darwinian), evolution. ${ }^{22}$ In Aurobindo's approach, by contrast, such a moral limitation on germ-line genetic engineering would seem unnecessary since it would be done in accord with the "integral knowledge" which is guiding the evolution of the cosmos toward its final realization. In this context, even germ-line genetic engineering would become a part of the practice of Aurobindo's Integral Yoga in its push for the perfection of cosmic evolution.

The above are some beginning thoughts on ethics and genetic engineering in Indian Philosophy with some comparisons to modern Western thought.

\section{Notes}

1. As quoted by S.K. Chakraborty, "Ethical and Moral Implications of New Technologies including Genetic Engineering." Berlin: Online Journal, http://www.here -now4u.de/eng (16/12/99).

2. As quoted by Richard Harland, Superstructuralism: The Philosophy of Structuralism and 
Post-Structuralism (London: Methuen, 1987), pp. 130-31.

3. Som Pal, Minister for Agriculture, Indian News Agency PTI Interview, April 26, 1998, Delhi.

4. From website, http://infoweb5. newsbank.com/cgi-b, Dec. 8, 1999.

5. PTI News Agency, New Delhi $\mathrm{BBC}$ Monitoring International Reports, BBC Worldwide Monitoring, March 10, 1998.

6. Xinhua News Agency, Delhi, "India's Caste System Changes Hindus' Genetic Makeup," Oct. 18, 1998.

7. Carmen Cassero, Rosalba Montana, Maria Arena and Guido Modiano, "The Distribution of Human Genetic Polymorphisms in India - with special reference to the Hindus," Atti Della Accademia Nazionale Dei Lincei, Roma, Vol. XV888/3 (1986), pp. 3-247.

8. Deutsche Press-Agentur,

"Indigenous Peoples protest against biocolonialism," Nov. 28, 1997.

9. "Monsanto Under Siege in India," Infonewsservice, http://www.ainfos.ca, Nov. 25, 1998.

10. "Suspicions Linger about Monsanto," The Times of India, Nov. 29, 1998, Business section.

11. P.S. Jaini, The Jaina Path of Purification (Berkeley, CA: University of California Press, 1979), pp. 107-33.
12. Ibid., p. 112.

13. Ibid, p. 167.

14. Patanjaliyogadarsanam

(Varanasi: Bharatiya Vidya Prakasana, 1963). A helpful English translation is by Rama Prasada (Allahabad, India: Bhubaneswari Asrama, 1924). Readily available, but more literal, is the translation by J. H. Woods (Varanasi: Molilal Banarsidass, 1966; Harvard Oriental Series, vol. 17). The key passages for the Yoga Sutra conception of karma are II: 1214 and IV: 7-9.

15. Encyclopedia of Bioethics, ed. by W.T. Reich (New York: Macmillan, 1995), "Human Genetic Engineering," p. 936.

16. . Ibid., 0.939; this is Engelhardt's viewpoint. For current Christian perspectives see Food for Thought by John Perry, SJ (Ottawa: Novalis, 2002) and Beyond Cloning, ed. by Ronald Cole-Turner (Harrisburgh: Trinity International, 2001).

17. Robert Minor, Sri Aurobindo: The Perfect and the Good. (Calcutta: Minerva, 1978), p. 103.

18. Tbid., p. 104.

19. Ibid.

20. See Minor's summary of Aurobindo's Life Divine, ibid., p. 104.

21. Encyclopedia of Bioethics, "Human Genetic Engineering,". p. 939.

22. Ibid. 